Cambridge Meeting of the International

THE International Union for Pure and Appiied Chemistry met at Cambridge on Sunday, June I7, under the presidency of Sir W. J. Pope, and carried out the programme previously outlined in these columns (June 16, p. 825). The countries which have now joined the Union are the followingThe Argentine, Australia, Belgium, Canada, Czechoslovakia, Denmark, France, Great Britain, Greece, Holland, Italy, Japan, Luxemburg, Norway, Peru, Poland, Portugal, Roumania, Spain, Switzerland, the United States of America, Uruguay, and Yougoslavia; over one hundred delegates representing the chemical interests of these countries were in attendance at Cambridge. A feature of the meeting was the presentation of several comprehensive reports on subjects which at the moment present special chemical interest; these were printed and distributed beforehand, and at the meeting brief summaries were presented by their authors, after which general discussions took place.

The report on "The Study of Soap Solutions and its Bearings upon Colloid Chemistry," presented by Prof. J. W. McBain, included a statement of the chief conclusions arrived at by its author in his extended studies of the properties of salts of the higher fatty acids. About one-half of the electrical conductivity of a soap solution is due to a negative carrier, which does not exhibit osmotic activity and is therefore colloidal; this is the ionic micelle, and consists of highly charged and solvated ionic particles. Accompanying the ionic micelle is the undissociated colloidal electrolyte, which consists of electrically neutral micelli. Interesting contributions to the discussion were made by Prof. H. E. Armstrong and Prof. W. D. Bancroft. Dr. E. K. Rideal presented a report on "Recent Developments in Contact Catalysis," in which the conception of Hardy and Langmuir, that adsorption of reactants occurs in monomolecular and orientated films, is shown capable of application to the reactions at the surface of charcoal, studied by Van Kruyt, and at the surface of the enzyme, oxidase, present in liver tissue, as studied by Hopkins.

\section{Union for Pure and Applied Chemistry.}

The report contributed by Prof. J. F. Thorpe and Dr. C. K. Ingold consisted in a summary of the recent work of the authors on "Some New Aspects of Tautomerism." It is claimed that the original definition of the term "tautomerism " should be broadened, in accordance with modern investigation, and that the term should apply to all reversible isomeric change; a reasoned classification of the various types of tautomeric change which have been more carefully studied during recent years is then given. The report by Prof. F. G. Hopkins, on "Chemical Mechanisms involved in the Oxidations which occur in the Living Body," describes the success which has attended the attempts to elucidate the nature of the oxidation processes involved in living tissues by a simple chemical mechanism. In the resulting discussion, Prof. C. Moureu drew a parallel between the course of these apparently complex reactions and the catalytic oxidation of aldehydes which he has himself studied. Mr. W. Barlow showed and described a number of solid models which he has devised for the interpretation, in accordance with the valency volume law, of the results of the X-ray analysis of crystalline materials by the Laue and Bragg method; incidentally he demonstrated an hitherto unknown mode of partitioning space into identical polyhedra.

A large proportion of the time of the meeting was devoted to the work of the numerous committees which are engaged in the attempt to systematise practice throughout the world in connexion with nomenclature, abbreviations, standard methods, tables of constants, and the like.

It was decided that the Union will hold its meeting next year in Copenhagen, on the invitation of the chemical representatives of Denmark. At the concluding ceremony honorary degrees of the University of Cambridge were conferred on a number of distinguished .visitors whose names were announced in the preliminary statement on the meeting (NATURE, June 16, p. 825).

\title{
Tercentenary of the Oxford Botanic Garden.
}

THROUGHOUT the three hundred years of its existence, the Oxford Botanic Garden can never have looked more radiant than it did on Saturday, June 23, when it welcomed the distinguished company which met to celebrate the tercentenary of its foundation. Sheltered by high and stately walls from the incessant north-east winds which in spring play havoc in more exposed gardens, it gave the impression of serene beauty, the more impressive because of the simplicity of the lines on which it has been laid out.

Those, however, who know the rigours of the Oxford climate will ascribe the luxuriance of growth of the plants in the garden rather to skill in cultivation than to good fortune with respect of site. For although the walls which surround the garden do, indeed, give shelter, the soil is none too kindly and the Thames water is too near the surface to make cultivation a light or easy task. It was, therefore, no less a tribute to their own perspicacity than to Mr. Baker, the superintendent of the gardens, that more than one speaker referred in terms of admiration to the skill in cultivation which the gardens displayed.

The Chancellor of the University, Lord Curzon, who presided at the tercentenary celebrations, spoke on gardens with the simple sincerity which proves his title to be ranked among the goodly company of true gardeners, and nothing in his speech gave more pleasure to the company which were met together under the trees of the garden than his reminiscences of the happy hours which as undergraduate and fellow he had passed in the Oxford Botanic Garden. For surely this old garden has for three centuries irradiated a happy influence on successive generations whose feet have walked therein and whose eyes have been refreshed by its scenes of peaceful beauty.

Sir David Prain, who followed the Chancellor, traced in a masterly way the history of the Garden from the time of its foundation, by the beneficence of Henry Lord Danvers, on St. James's Day. (July 25), I622. He reminded his hearers that it was in this Garden that the first greenhouses erected in England were put up, and that it was there that experiments were first made in methods of heating them. Bobert the elder and the younger, men of great wisdom ; Morison, the great professor of botany and a pioneer of systematic botany; Sherard, the founder of the chair which bears his name; Sibthorpe, who deserves the title of a great botanical explorer; and Daubeny, versatile and gencrous,

NO. 2801, VOL. II 2$]$ 